\title{
Pendugaan Intensitas Serangan Penyakit BLB (Bacterial Leaf Blight) pada Tanaman Padi melalui Pendekatan Citra Multispektral
}

\section{Estimation of BLB (Bacterial leaf blight) Disease Attack Intensity on Rice Plant through Multispectral Image Approach}

\author{
Gusti Bagus Eka Chandra, I Made Anom S. Wijaya*, Yohanes Setiyo \\ Program Studi Teknik Pertanian, Fakultas Teknologi Pertanian Universitas Udayana, Badung, Bali, Indonesia), \\ *email: anomsw@unud.ac.id
}

\begin{abstract}
Abstrak
Penyakit Bacterial Leaf Blight (BLB) merupakan salah satu penyakit yang berbahaya bagi tanaman padi. Penyakit ini bisa menyerang di setiap fase pertumbuhan. Perhitungan intensitas serangan penyakit BLB saat ini masih dilakukan secara manual. Diperlukan pengembangan teknologi dalam pendugaan intensitas serangan penyakit BLB melalui citra multispektral. Penelitian ini bertujuan untuk (1) untuk mendapatkan nilai korelasi terbaik antara intensitas serangan penyakit BLB dengan parameter citra multispektral (2) Untuk mendapatkan persamaan pendugaan intensitas serangan penyakit BLB berdasarkan pendekatan citra multispektral. Drone DJI Inspire 1 dengan kamera multispektral digunakan untuk menangkap gambar petak padi. Pengolahan data citra multispektral menggunakan Agisoft Photoscan dan software QGIS 3.8. Berdasarkan dari hasil akuisisi, citra multispektral menghasilkan citra band red, NIR, green, red edge, RGB yang kemudian diolah menjadi transformasi citra NDVI, EVI, dan NDRE. Dari ketiga parameter citra multispektral, nilai NDVI memiliki tingkat korelasi yang lebih kuat dengan koefisien determinasi sebesar 97,5\% dan menghasilkan persamaan linier sebagai berikut $\mathrm{y}=-419,6+169,3$. Dalam perhitungan nilai eror parameter NDVI memilikinilai eror paling rendah dibandingkan parameter EVI dan NDRE yaitu sebesar 4,64\% dengan akurasi pendugaan $95,36 \%$. Citra multispektral dapat digunakan dalam pendugaan intensitas serangan penyakit BLB pada tanaman padi karena menghasilkan nilai korelasi yang sangat kuat, dan akurasi pendugaan yang tinggi dengan nilai eror yang rendah tidak melebihi $10 \%$.
\end{abstract}

Kata kunci: Intensitas serangan, Multispektral, Pendugaan, Penyakit BLB

\begin{abstract}
Abtract
Bacterial Leaf Blight (BLB) is a disease that is dangerous for rice plants. This disease can attack in every phase of growth. Calculation of BLB disease attack intensity is currently still used manually method. Technology development is needed in estimating the intensity of BLB disease through multispectral imagery. This study aims (1) to get the best correlation value between the intensity of BLB disease attack with multispectral image parameters (2) to get the equation for estimating the intensity of BLB based on multispectral images parameter. Drone DJI Inspire 1 with a multispectral camera is used to captured the paddy field. The captured images was processed using Agisoft Photoscan and QGIS 3.8 software. Based on the results of the acquisition, multispectral images produce red, NIR, green, red edge, RGB band images which were then transformed into NDVI, EVI, and NDRE images. Of the three multispectral image parameters, NDVI values have a stronger correlation level with a determination coefficient of $97.5 \%$ and produce the following linear equation $y=-419.6+169.3$. In calculating the NDVI parameter error value has the lowest error value compared to the EVI and NDRE parameters which is $4.64 \%$ with an accuracy estimate of $95.36 \%$. Multispectral imagery can be used in estimating the intensity of BLB disease attacks in rice plants because it produces a very strong correlation value, and high estimation accuracy with a low error value does not exceed $10 \%$.
\end{abstract}

Keywords: Intensity of attack, Multispectral, Estimation, BLB disease.

\section{PENDAHULUAN}

Padi (Oryza sativa) merupakan salah satu tanaman pangan utama di dunia (Mudingotto et al., 2010). Di Indonesia, padi merupakan bahan makanan pokok sehingga kebutuhan padi semakin meningkat setiap tahunnya (Siregar, 2007). Kendala yang dihadapi dalam praktek budidaya padi semakin beragam, salah satu kendala yang dihadapi dalam praktek budidaya padi adalah serangan hama dan penyakit pada tanaman padi. Salah satu penyakit yang menyerang tanaman padi adalah penyakit Bacterial Leaf Blight (BLB). Bacterial leaf blight (BLB) merupakan salah satu penyakit tanaman padi yang sangat penting di 
negara-negara penghasil padi di dunia, termasuk di Indonesia (Sudir S, 2018). Di Indonesia, keberadaan penyakit BLB dilaporkan sejak tahun 1950an pada tanaman padi muda di daerah Bogor dengan gejala layu. Pada awalnya penyakit ini dinamai kresek dan patogennya dinamai Xanthomonaskresek (Untung K, 2010).Menurut data dari Unit Pelaksana Teknis Balai Perlindungan Tanaman Pangan dan Hortikultura (UPT. BPTPH), pada tahun 2018 sampai dengan 2019tercatat penyakit BLB atau penyakit kresek memiliki luas total serangan sebesar 3809 ha. Secara visual penyakit BLB susah untuk dideteksi, penyakit ini tidak terlihat oleh mata, diperlukan ketelitian dalam mengidentifikasi penyakit ini.

Pada saat ini perhitungan intensitas serangan penyakit pada tanaman padi masih dilakukan dengan metode manual tanpa alat bantuan dan membutuhkan waktu yang cukup lama. Menurut Andika (2019) perhitungan intensitas serangan penyakit dapat dilakukan dengan cara mengolah data citra NDVI untuk menduga intensitas serangan penyakit blas pada padi berdasarkan nilai NDVI dan mendapatkan nilai eror yang rendah dan akurasi pendugaan yang tinggi.

NDVI merupakan salah satu algoritma indeks vegetasi yang didapatkan dari hasil transformasi citra band red, dan band nearinfrared (NIR). Indeks vegetasi merupakan suatu bentuk transformasi spektral yang diterapkan terhadap citra multisaluran untuk menonjolkan aspek kerapatan vegetasi ataupun aspek lain yang berkaitan dengan kerapatan, misalnya biomassa Leaf Area Index (LAI), konsentrasi klorofil dan sebagainya. Band red dan band NIR merupakan salah satu band yang dimiliki oleh citra multispektral. Dalam bidang pertanian citra multispektral biasanya digunakan dalam pengecekan tanaman yang sakit.Drone yang dilengkapi dengan file kamera multispektral di atas data lapangan dan mengumpulkan data gambar.Data tersebut kemudian ditransmisikan secara nirkabel ke komputer setelah pengambilan gambar data citra multispektral dapat dilihat di dalam komputer dalam warna yang berbeda misalnya merah dan hijau.Jika area merah menandai tanaman yang sakit petani tahu area mana yang perlu disemprot dengan pestisida (Pautasso M, 2018). Dalam penelitian ini algoritma indeks vegetasi yang digunakan adalah NDVI, EVI, dan NDRE. Perhitungan indeks vegetasi juga bisa dilakukan melalu satelit tetapi memiliki beberapa kekurangan seperti biaya operasional yang mahal dan real time data yang lama.

Dalam perkembangan teknologi di bidang pertanian khususnya perhitungan intensitas serangan penyakit BLB (Bacterial leaf blight). Memerlukan kombinasi antara citra digital dengan penginderaan jarak jauh yang diharapkan bisa mempermudah menghitung intensitas serangan penyakit BLB. Berdasarkan hal tersebut, maka perlu dilakukan penelitian tentang pendugaan intensitas serangan penyakit Bacterial leaf blight (BLB) pada tanaman padi melalui pendekatan citra multispektral. Adapun tujuan dari penelitian ini adalah untuk mendapatkan nilai korelasi terbaik antara intensitas serangan penyakit BLB dengan parameter citra multispektral dan untuk mendapatkan persamaan pendugaan intensitas serangan penyakit Bacterial leaf blight (BLB) berdasarkan pendekatan citra multispektral.

\section{METODE PENELITIAN}

\section{Tempat dan Waktu Penelitian}

Penelitian ini dilaksanakan di Subak Ayung, Desa Buduk, Kecamatan Mengwi, Kabupaten Badung, dan di Subak Tungkub Dua, Desa Kaba-Kaba, Kecamatan Kediri, Kabupaten Tabanan. Penelitian ini dilakukan pada bulan September - Oktober 2019.

\section{Alat dan Bahan}

Alat-alat yang yang digunakan dalam melakukan penelitian ini meliputi akuisisi citra dan alat pengolahan citra serta alat ukur. Alat akuisisi citra yang digunakan yaitu drone DJIInspire 1 yang dilengkapi kamera Multispektral dan Ipad Pro yang dilengkapi dengan aplikasi DJI GSPro untuk pembuatan jalur terbang (Waypoint) serta control drone DJI Inspire 1 dan aplikasi Parrot Seqouia untuk Setting Kamera Multispektral. Alat pengolahan citra yang digunakan berupa komputer dengan spesifikasi sebagai berikut : intel pentium $(R)$ Core $i 5$, RAM 6 GB, VGA Radeon RX550 2GB,Hard disk1000 GB yang dilengkapi dengan aplikasi Agisoft Photoscan, dan QGIS 3.8. Alat ukur yang digunakan adalah GPS.

Bahan dari penelitian ini adalah padi varietas ciherang yangterserang penyakit BLB, pada fase generatif padi yang berusia 109 hari setelah tanam (HST) dengan jumlah sampel 75 titik yang terserang penyakit BLB.

\section{Pelaksanaan Penelitian}

Penelitian ini dilakukan dengan beberapa tahapan yaitu akuisisi citra multispektral pada ketinggian 40 meter, perhitungan intensitas serangan penyakit, mosaicking citra multispektral dan pengolahan citra multispektral, korelasi intensitas serangan dengan nilai NDVI, EVI, NDRE, validasi data, dan klasifikasi Intensitas Serangan Penyakit BLB dengan nilai NDVI, EVI, NDRE.

\section{Akusisi Citra Multispektral pada Ketinggian 40 Meter}

Pengambilan foto udara dilakukan menggunakan drone DJI Inspire 1 dengan tambahan kamera multispektral. Pengambilan foto udara dilakukan 
pada pukul $08.00-10.00$ pagi dengan rentang intensitas cahaya $20.000-60.000$ lux dengan ketinggian 40 meter kecepatan $6,3 \mathrm{~m} / \mathrm{s}$ interval pengambilan gambar 1,5 second. Sebelum melakukan akuisisi citra perlu dilakukan pembuatan jalur terbang (waypoint) pada aplikasi DJI GSPro dan Settingkamera multispektral pada aplikasi Parrot Seqouia. Saat setting kamera multispektral tunggu hingga notifikasi Readyberubah menjadi GPSLAPSE RUNNING setelah itu drone sudah bisa diterbangkan dengan menekan Start to Fly.

\section{Metode Perhitungan Intensitas Penyakit BLB}

Metode perhitungan intensitas serangan penyakit dilakukan dengan cara menentukan titik sampel secara diagonal perpetak. Perhitungan intensitas dilakukan pada padi yang terserang penyakit BLB dengan cara menghitung skor kerusakan pada padi dengan standar POPT.

\section{Pengolahan Citra Multispektral}

Setalah foto citra didapatkan akan dilanjutkan dengan proses pengolahan citra multispektral menggunakan band yang dimiliki oleh kamera multispektral, kamera multispektral memiliki 5 band yaitu band NIR, Red, Green, RGB dan Red Edge yang akan digunakan untuk mencari 3 nilai indeks vegetasi yaitu NDVI, EVI, dan NDRE. Perhitungan nilai NDVI, EVI, dan NDRE dilakukan di aplikasi QGIS dengan bantuan raster calculator. Sebelum perhitungan ketiga parameter tersebut hasil foto citra multispektral akan melalui proses Mosaicking, proses ini dilakukan dengan bantuan aplikasi Agisoft Photoscan. Mosaickingmerupakan suatukegiatan yang menggabungkan foto citra untuk menjadikan satu kesatuan foto citra yang utuh. Foto citra yang didapatkan terdiri dari ketinggian 40meter.

\section{Korelasi Intensitas Serangan dengan Nilai NDVI, EVI, dan NDRE.}

Analisis korelasi merupakan suatu salah satu analisis statitk yang cukup penting dan berkaitan dengan masalah permodelan matematik dari suatu pasangan data hasil pengamatan. Berdasarkan analisis korelasi tersebut, maka diperoleh model persamaan yang selanjutnya digunakan untuk menduga intensitas serangan penyakit BLB tanaman padi.Menurut Kismianti (2010), nilai korelasi 0 - 0,25 menunjukan korelasi sangat lemah, nilai korelasi $0,25-0,5$ menunjukan korelasi cukup, nilai korelasi 0,5 - 0,75 menunjukan korelasi kuat, nilai korelasi $0,75-1$ menunjukan korelasi sangat kuat.

\section{Validasi}

Tujuan dari validasi adalah untuk mengetahui presentase nilai eror yang diberikan oleh sistem pendugaan intensitas serangan penyakit BLB pada tanaman padi. Dalam penelitian ini data yang divalidasi adalah data perhitungan intensitas serangan penyakit BLB. Validasi data diukur dengan menggunakan metode RMSE (Root Mean Squer Error). Menurut Hakim (2011), jika nilai RMSE kurang atau sama dengan 10\% maka aplikasi tersebut dapat dikatakan akurat.

\section{Klasifikasi Intensitas Serangan Penyakit BLB dengan Nilai NDVI, EVI, dan NDRE.}

Klasifikasi nilai NDVI, EVI, dan NDRE dilakukan untuk menentukan rentang nilai ketiga parameter berdasarkan kategori intensitas serangan penyakit.Rentang nilai ketiga parameter didapatkan melalui perhitungan persamaan pendugaan.Menurut Direktorat Tanaman Pangan (2007), kategori intensitas serangan untuk jenis penyakit dapat digunakan pedoman sebagai berikut : 1. Intensitas serangan (IS) ringan dengan rentang persentase $0>$ IS $\leq 11 \%$, Intensitas serangan (IS) sedang dengan rentang persentase $11>$ IS $\leq 25 \%$, Intensitas Serangan (IS) berat dengan rentang persentase $25>$ IS $\leq 75 \%$, Intensitas Serangan (IS) puso dengan rentang persentase $75>$ IS $\leq 100 \%$.

\section{HASIL DAN PEMBAHASAN}

\section{Citra Multispektral}

Hasil akuisisi citra multispektral menghasilkan foto citra multispektral terdiri dari 5 kelompok hasil citra yang dibagi berdesarkan band dari kamera multispektral yang digunakan saat akuisisi data diantaranya band RGB, band Red, band NIR, band Red Edge, dan band Green. Setelah foto citra multispektral didapatkan selanjutnya dilakukan proses mosaicking citra multispektral. Proses mosaicking citra dilakukan pada aplikasi Agisoft Photoscan dengan melalui beberapa tahapan proses yaitu yang pertama proses align photos, pembangunan dense clout point, pembangunan model 3D (mesh), pembangunan model texture, pembangunan DEM, dan pembangunan orthophoto. Jika seluruh tahapan sudah dilalui maka hasil mosaicking citra akan menghasilkan foto orthomosaic yang sudah dapat disimpan dengan tipe file Geotiff atau Tif. Lamanya proses mosaicking citra pada aplikasi agisoft photoscan tergantung dari seberapa banyaknya foto yang dimosaicking, semakin banyak foto yang dimosaicking maka semakin lama prosesnya. Hasil mosaicking citra multispektral dapat dilihat pada Gambar 1. 


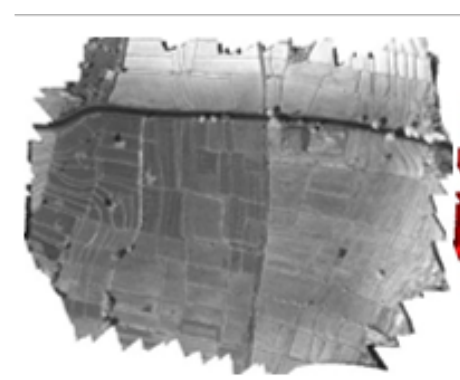

Band NIR

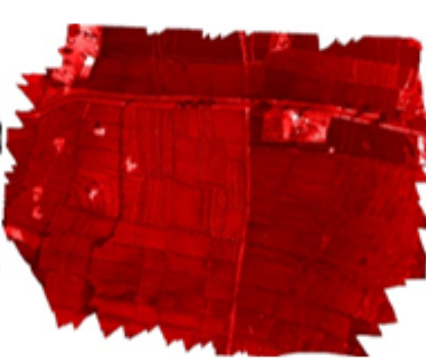

Band Red

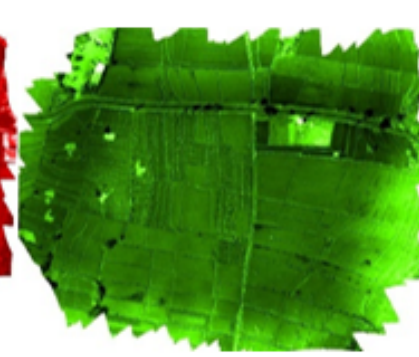

Band Green

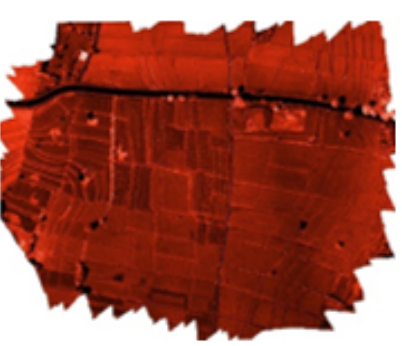

Band Red Edge

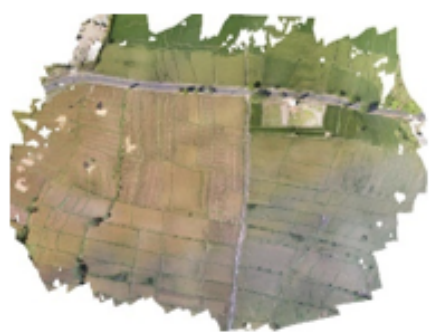

Band RGB

Gambar 1. Hasil Mosaicking Citra Multispektral

\section{Pengolahan Citra Multispektral}

Proses pengolahan citra multispektral pada penelitian ini menghasilkan citra NDVI, EVI, dan NDRE. Jika proses kombinasi citra orthomosaic sudah dilakukan maka akan dilanjutkan dengan proses perhitungan nilai dari NDVI, NDRE, dan EVI. Sebelum melakukan proses perhitungan nilai indeks vegetasi dilakukan proses pemasangan koordinat titik pengambilan sampel (PlotCoordinat). Sebelum melakukan Plot koordinat akan dilakukan proses perhitungan koordinat dari degree ke decimal contoh perhitungannya: $7^{\circ} 48^{\prime} 10.2$ "S ( 7 derajat 48 menit 10,2 detik) $\mathrm{S}=7+(48 / 60)+(10,2 / 3600)=7,8028333$. Hasil kombinasi citra multispektral menghasilkan citra NDVI, EVI, dan NDRE sebagai berikut:

\section{Citra Normalized Difference Vegetation Index (NDVI)}

Kombinasi matematis antara band NIR dan band red menghasilkan citra Normalized Difference Vegetation Index (NDVI) dengan rumus: NDVI = (NIR - Red) / (NIR + Red). Citra NDVI dapat mengidentifikasi tanaman yang sakit dan sehat, contohnya warna merah menandakan tanaman yang sakit dan warna hijau menandakan tanaman yang sehat. Citra NDVI dapat dilihat pada Gambar 2.

\section{Citra Enhanced Vegetation Index (EVI)}

Citra Enhanced Vegetation Index (EVI) merupakan citra hasil kombinasi matematis antara band Blue, band Red, dan band NIR. Formula yang digunakan dalam mengolah citra EVI adalah EVI $=2,5 \times(\mathrm{NIR}$ - Red) / (NIR + $6 \times$ Red $-7,5 \times$ Blue +1$)$. Citra EVI dapat dilihat pada Gambar 3 .

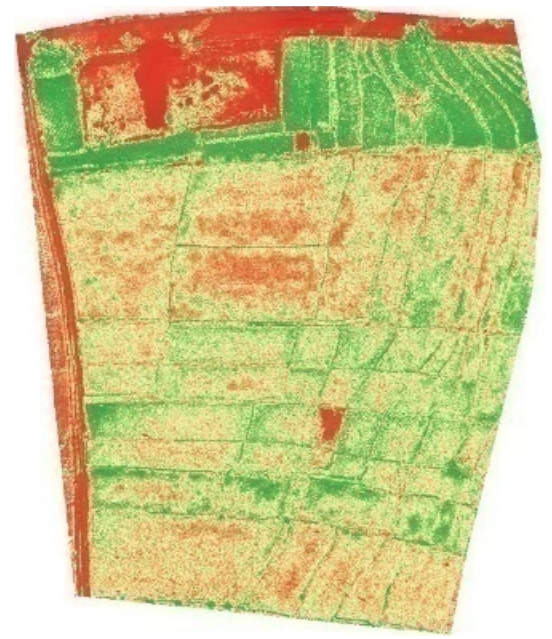

Gambar 2.Citra NDVI

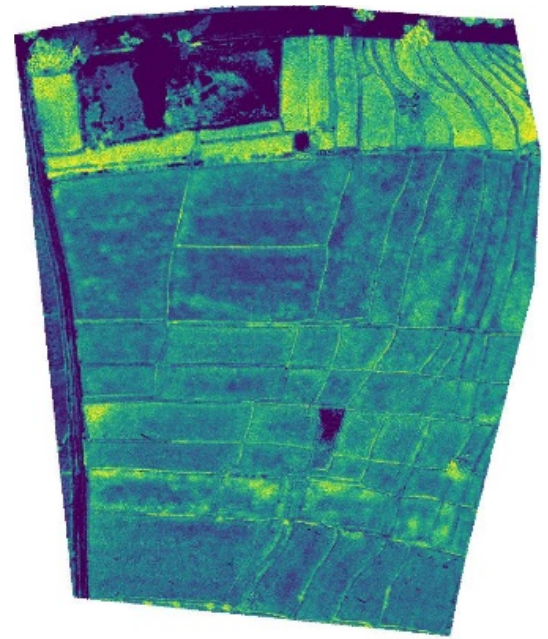

Gambar 3. Citra EVI

Citra Normalized Difference Red Edge (NDRE) 
Citra Normalized Difference Red Edge (NDRE) merupakan citra hasil kombinasi matematis antara band NIR dan band Red Edge. Formula yang digunakan dalam kombinasi matematis citra NDRE adalah NDRE $=($ NIR - Red Edge $) /($ NIR + Red Edge).

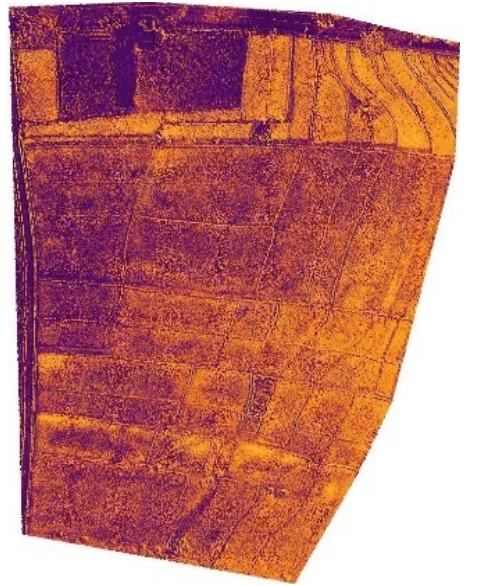

Gambar 4. Citra NDRE

\section{Analisis Korelasi Intensitas Serangan Penyakit BLB dengan Nilai NDVI, NDRE,EVI Menggunakan Persamaan Regresi}

Kekuatan analisis regresi dapat ditujukan dengan koefisien determinasi dari persamaan yang didapatkan antara nilai NDVI, NDRE, dan EVI dan nilai intensitas serangan penyakit BLB. Dari ketiga nilai indeks vegetasi tersebut akan dibandingkan manakah parameter terbaik dengan nilai korelasi yang paling kuat.

Setelah nilai korelasi intensitas serangan penyakit dengan nilai NDVI, NDRE, dan EVI menggunakan persamaan regresi telah didapatkan, selanjutnya akan dilakukan validasi data untuk menghitung seberapa besar nilai eror yang didapatkan dalam pendugaan intensitas serangan penyakit BLB berdasarkan nilai NDVI, NDRE, dan EVI. Hasil Korelasi intensitas serangan dengan nilai NDVI, EVI, dan NDRE dapat dilihat sebagai berikut :

\section{Korelasi Intensitas Serangan dengan Nilai NDVI}

Dari 75 sampel yang didapat data yang digunakan untuk analisis korelasi dipilih secara acak agar mendapatkan hasil nilai korelasi yang lebih baik. Pada saat pemilihan sampel acak dilakukan sortasi data dari yang terendah sampai tertinggi. Berdasarkan analisis regresi dan korelasi yang dilakukan antara nilai NDVIdan nilai intensitas, hasil dari nilai NDVI memiliki tingkat korelasi yang paling baik dan memiliki nilai koefisien determinasi terbesar diantara nilai NDRE dan EVI. Grafik hubungan nilai NDVI dengan intensitas serangan penyakit dapat dilihat pada Gambar 5 .
Dari Gambar 5 dapat diketahui sebaran data mengikuti pola linear. Hal ini ditunjukan oleh koefisien determinasi dari data terhadap persamaan sebesar 0,975 atau $97,5 \%$. Koefisien determinasi sebesar $97,5 \%$ artinya $97,5 \%$ data berkorelasi sangat kuatkarena hasil korelasi melebihi 0,75 atau $75 \%$ dan $97,5 \%$ data intensitas serangan penyakit BLB dapat diterangkan oleh nilai NDVI. Persamaan regresi yang didapat dari grafik adalah sebagai berikut :

Keterangan :

$$
y=-419,6 x+169,3
$$

$\mathrm{y}=$ Intensitas serangan penyakit BLB

$\mathrm{x}=$ Nilai NDVI

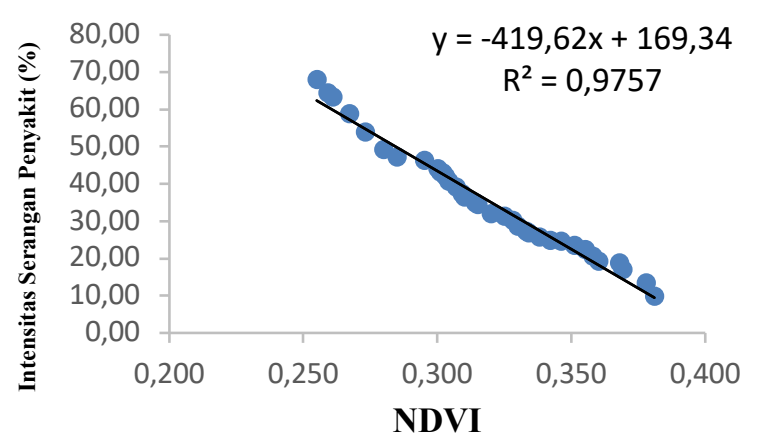

Gambar 5. Grafik hubungan nilai NDVI dengan intensitas serangan penyakit

Korelasi Intensitas Serangan dengan Nilai EVI

Berdasarkan analisis regresi dan korelasi yang dilakukan antara nilai EVI dengan nilai intensitas, hasil korelasi dari nilai EVI memiliki koefisien determinasi sebesar 88,38\% nilai tersebutlebih rendah dibandingkan dengan nilai NDVI yang memiliki koefisien determinasi sebesar 97,5\%.Grafik hubungan nilai EVI dengan intensitas serangan penyakit dapat dilihat pada Gambar 6 .

Dari Gambar 2 dapat diketahui sebaran data tidak terlalu mengikuti pola linear. Hal ini ditunjukan oleh koefisien determinasi dari data terhadap persamaan yang kurang dari $90 \%$. Koefisien determinasi yang didapatkan dari data terhadap persamaan sebesar0,8838 atau $88,38 \%$. Koefisien determinasi $88,38 \%$ artinya $88,38 \%$ data berkorelasi sangat kuat karena melebihi 0,75 atau $75 \%$ dan $88,38 \%$ intensitas serangan penyakit BLB dapat diterangkan oleh nilai EVI. Persamaan regresi yang didapat dari grafik adalah sebagai berikut :

Keterangan :

$$
y=-326,8 x+107,83
$$

$\mathrm{y}=$ Intensitas serangan penyakit BLB

$\mathrm{x}=$ Nilai EVI 


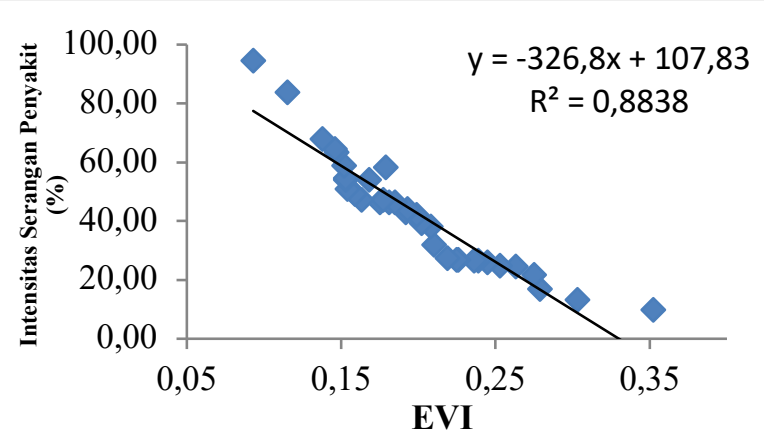

Gambar 6. Grafik hubungan nilai EVI dengan intensitas serangan penyakit

Korelasi Intensitas Serangan dengan Nilai NDRE Berdasarkan analisis regresi dan korelasi yang dilakukan antara nilai NDRE dengan nilai intensitas, hasil analisis regresi dan korelasi dari nilai NDRE memiliki koefisien determinasi sebesar $87,27 \%$ nilai tersebutlebih rendah dibandingkan dengan nilai NDVI yang memiliki koefisien determinasi sebesar $97,5 \%$ dan nilai EVI yang memiliki koefisien determinasi sebesar $88,38 \%$.Grafik hubungan nilai NDRE dengan intensitas serangan penyakit dapat dilihat pada Gambar 7 .

Dari Gambar 3 dapat diketahui sebaran data tidak terlalu mengikuti pola linear. Hal ini ditunjukan oleh koefisien determinasi dari data terhadap persamaan yang kurang dari $90 \%$. Koefisien determinasi yang didapatkan dari data terhadap persamaan sebesar0,8727 atau $87,27 \%$. Koefisien determinasi $87,27 \%$ artinya $87,27 \%$ data berkorelasi sangat kuat karena hasil korelasi melebihi $75 \%$ dan $87,27 \%$ data intensitas serangan penyakit BLB dapat diterangkan oleh nilai NDRE. Persamaan regresi yang didapat dari grafik adalah sebagai berikut:

Keterangan :

$$
y=-618,72+159,01
$$

$\mathrm{y}=$ Intensitas serangan penyakit BLB

$\mathrm{x}=$ Nilai NDRE

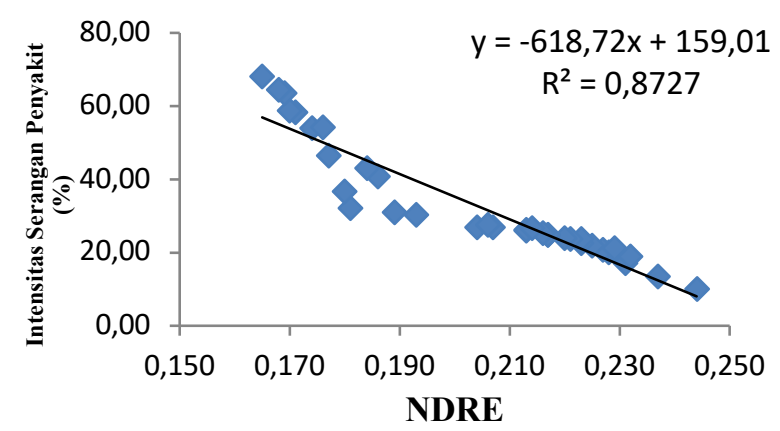

Gambar 7. Grafik hubungan nilai NDRE dengan intensitas serangan penyakit

\section{Validasi}

Validasi data dilakukan untuk menghitung seberapa besar nilai eror yang didapatkan dalam pendugaan intensitas serangan penyakit BLB. Dalam melakukan validasi data untuk mencari nilai pendugaan nilai intensitas serangan penyakit akan dihitung menggunakan rumus dari persamaan regresi yang didapatkan sebelumnya dari hasil analisis regresi dan korelasi intensitas serangan dengan NDVI, EVI, NDRE.

Berdasarkan data yang didapatkan pada intensitas serangan dari sistem pendugaan menunjukan perbedaan data dengan hasil sebenarnya. Akurasi dari sistem pendugaan setelah dianalisis dengan menggunakan metode RMSE mendapatkan nilai eror sebesar 4,64\% untuk parameter NDVI, yang artinya terdapat simpangan kesalahan sebesar 4,64\% intensitas serangan penyakit BLB dengan hasil sebenarnya. Untuk parameter EVI nilai eror yang didapatkan sebesar 5,84\% untuk parameter NDRE nilai eror yang didapatkan sebesar 7,95\%. Dari besarnya nilai RMSE dapat dikatakan bahwa program akurat dalam menduga intensitas serangan yang terjadi karena eror yang dihasilkan kurang dari $10 \%$ (Hakim, 2011). Nilai eror didapatkan disebabkan oleh kurang akuratnya GPS yang digunakan dalam titik pengambilan sampel, sehingga mengakibatkan kesalahan perhitungan dari nilai NDVI, EVI dan NDRE.

Untuk parameter NDVI besar nilai RMSE yang didapatkan pada penelitian adalah sebesar 4,46\% maka akurasi pendugaan yang didapatkan yaitu $95,36 \%$. Hal ini menunjukan bahwa 95,36\% data yang didapatkan dengan pendugaan menghasilkan data tepat atau sama dengan yang dikumpulkan. Untuk parameter EVI besar nilai RMSE yang didapatkan adalah sebesar 5,84\% maka akurasi pendugaan yang didapatkan yaitu 94,16\%. Untuk parameter NDRE besar nilai RMSE yang didapatkan adalah sebesar 7,95\% maka akurasi pendugaan yang didapatkan yaitu $92,05 \%$. Nilai pendugaan intensitas serangan berdasarkan parameter NDVI memiliki nilai eror yang lebih kecil dibandingkan parameter EVI dan NDRE yang artinya parameter NDVI memiliki hasil yang lebih baik untuk penelitian ini. Semakin besar akurasi program yang dibuat maka semakin akurat atau semakin mendekati kenyataan pendugaan yang dibuat.Dalam proses validasi ini juga didapatkan hasil koefisien determinasi dari intensitas serangan penyakit dengan pendugaan intensitas penyakit yang didapatkan berdasarkan ketiga parameter yaitu NDVI, EVI, dan NDRE. Koefisien determinasi hasil validasi berdasarkan parameter NDVI, EVI, dan NDRE dapat dilihat pada Gambar 8, Gambar 9, dan Gambar 10.

Keterangan :

$\mathrm{x}$ : Nilai Pendugaan Intensitas Serangan (\%)

$y$ : Nilai Intensitas Serangan Penyakit (\%) 


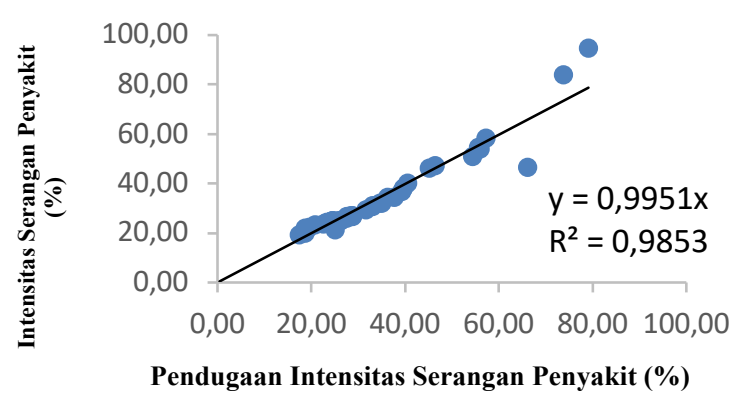

Gambar 8. Koefisien determinasi berdasarkan hasil validasi parameter NDVI

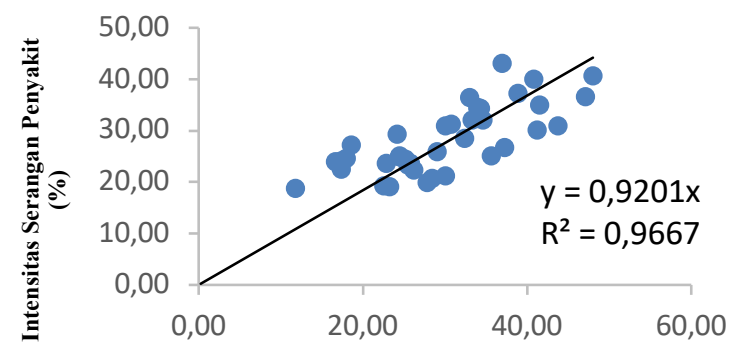

Pendugaan Intensitas Serangan Penyakit (\%)

Gambar 9. Koefisien determinasi berdasarkan hasil validasi parameter EVI

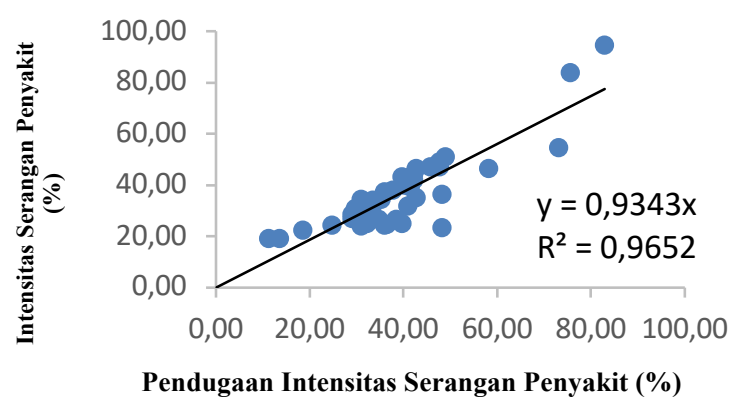

Gambar 10. Koefisien determinasi berdasarkan hasil validasi parameter NDRE

Dapat dilihat pada Gambar 4 koefisien determinasi dari analisis validasi berdasarkan parameter NDVI memiliki nilai sebesar 0,9184 atau $91,84 \%$ yang artinya nilai intensitas serangan penyakit dan nilai pendugaan intensitas serangan penyakit berkorelasi sangat kuatdengan koefisien determinasi91,84\%. Dari Gambar 5 dapat dilihat untuk parameter EVI memiliki koefisien determinasi sebesar 0,3108 atau $31,08 \%$ yang artinya parameter EVI memiliki korelasi yang cukup dengan nilai korelasi sebesar $31,08 \%$. Dari gambar 6 dapat dilihat untuk parameter NDRE memiliki koefisien determinasi sebesar 0,758 atau $75,8 \%$ yang artinya nilai intensitas serangan penyakit dan nilai pendugaan intensitas serangan penyakit berkorelasi sebesar 75,8\%.

Kategori Intensitas Serangan Penyakit BLB Berdasarkan Nilai NDVI, EVI, dan NDRE
Berdasarkan dari persamaan pendugaan intensitas serangan penyakit BLB dapat dilihat klasifikasi rentang nilai NDVI, EVI, dan NDRE dari kategori intensitas serangan. Klasifikasi yang dibuat berdasarkan dari pendugaan pengamatan dan pelaporan perlindungan tanaman pangan.

Kategori intensitas serangan penyakit BLB berdasarkan nilai NDVI dapat dibagi menjadi 4 kategori serangan yaitu serangan ringan, sedang, berat, dan puso. Klasifikasi rentang nilai NDVI dapat dilihat pada Gambar 11. Rentang nilai NDVI untuk setiap kategori intensitas serangan penyakit BLB yaitu intensitas serangan ringan mendapat rentang nilai NDVI yaitu $0,403-0,377$. Intensitas serangan sedang mendapat rentang nilai NDVI yaitu 0,376 0,343 . Intensitas serangan berat mendapat rentang nilai NDVI yaitu $0,342-0,224$. Intensitas serangan puso mendapat rentang nilai NDVI yaitu 0,223 0,165 .

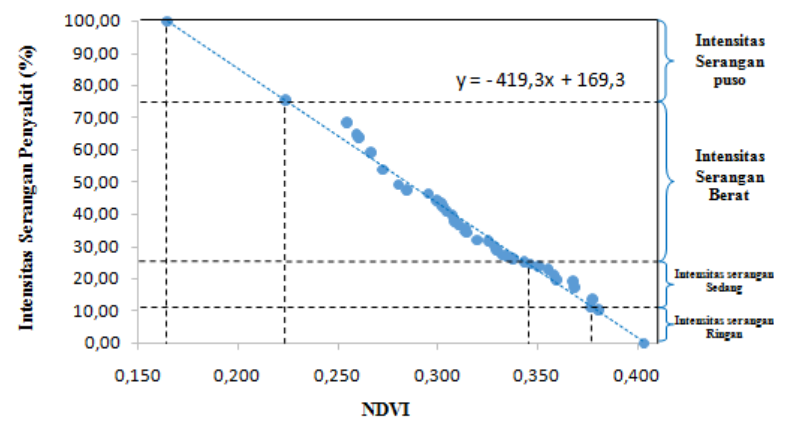

Gambar 11. Klasifikasi rentang nilai NDVI

Klasifikasi rentang nilai EVI dapat dilihat pada Gambar 12. Rentang nilai EVI untuk setiap kategori intensitas serangan penyakit BLB yaitu intensitas serangan ringan mendapat rentang nilai EVI yaitu0,329 - 0,296. Intensitas serangan sedang mendapat rentang nilai EVI yaitu 0,298 - 0,253. Intensitas serangan berat mendapat rentang nilai EVI yaitu 0,252 - 0,100. Intensitas serangan puso mendapat rentang nilai EVI yaitu 0,099 - 0,023.

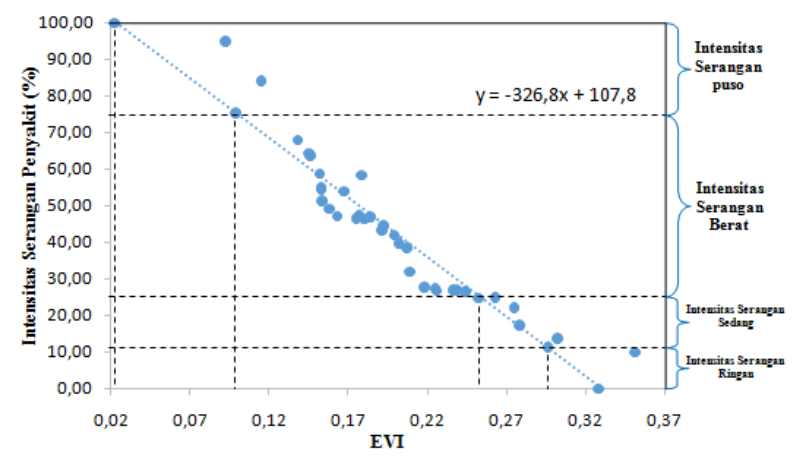

Gambar 12. Klasifikasi rentang nilai EVI

Klasifikasi rentang nilai NDRE dapat dilihat pada Gambar 13. Rentang nilai NDRE untuk setiap kategori intensitas serangan penyakit BLB yaitu intensitas serangan ringan mendapat rentang nilai 
NDRE yaitu 0,256 - 0,239. Intensitas serangan sedang mendapat rentang nilai NDRE yaitu 0,238 0,216 . Intensitas serangan berat mendapat rentang nilai NDRE yaitu $0,215-0,135$. Intensitas serangan puso mendapat rentang nilai NDRE yaitu 0,134 0,095 .

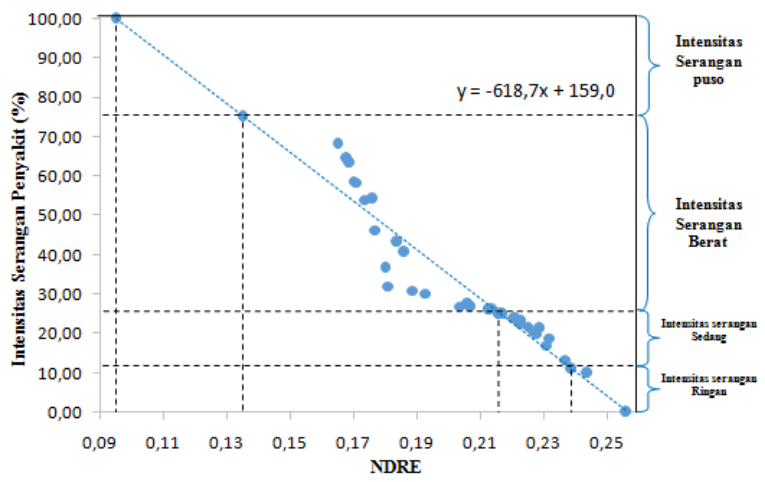

Gambar 13. Klasifikasi rentang nilai NDRE

\section{KESIMPULAN DAN SARAN}

\section{Kesimpulan}

Berdasarkan hasil dari penelitian yang telah dilakukan maka dapat disimpulkan sebagai berikut : Dari ketiga parameter citra multispektral, nilai NDVI memiliki tingkat korelasi yang lebih kuat dibandingkan dengan nilai NDRE dan EVI yaitu memiliki nilai koefisien determinasi sebesar 97,5\% dengan persamaan linier sebagai berikut $y=-419,6 x$ + 169,3.Berdasarkan hasil analisis korelasi dan validasi data citra multispektral dapat digunakan dalam pendugaan intensitas serangan penyakit BLB karena menghasilkan persamaan regresi dengan nilai korelasi yang sangat kuat dan akurasi pendugaan yang tinggi dengan nilai eror yang rendah tidak melebihi $10 \%$.

\section{Saran}

Dalam melakukan pendugaan intensitas serangan penyakit BLB melalui foto udara disarankan memperhatikan batasan - batasan yang ada dalam penelitian ini. Seluruh tahapan analisis harus didasarkan pada standar operasi prosedur sehingga mendapatkan hasil sesuai harapan. Dalam pengembangan program pendugaan intensitas serangan penyakit BLB, hendaknya dilakukan dengan spesifikasi alat GPS yang lebih tinggi sehingga menghasilkan detail informasi geospasial yang lebih detail sehingga mendapatkan nilai eror pendugaan yang rendah.

\section{DAFTAR PUSTAKA}

Andika, I. M. P. C., Wijaya, I. M. A. S., \& Gunadnya, I. B. P. 2019. Pendugaan Intensitas Serangan Penyakit Blas pada Tanaman Padi Melalui
Pendekatan Citra NDVI (Normalized Difference Vegetation Index). Jurnal BETA (Biosistem dan Teknik Pertanian), 7(2), 287296.

Hakim, A. F. 2011. Perancangan Sistem Informasi Pengukuran Konduktivitas Hidraulik Tidak Jenuh Tanah dengan Sensor Tensiometer dan Higrometer Digital. SKRIPSI-S1 Jurusan Teknik Elektro Fakultas Teknik Universitas Jember.

Kismiantini 2010. "Analisis Regresi”. Jurusan Pendidikan Matematika, Fakultas Matematika Dan Ilmu Pengetahuan Alam, Universitas Negeri Yogyakarta: Di Yogyakarta.

Mudingotto, P. J., Tusiime, G., Asea, G., Rubaihayo, P. R., Gibson, P. 2010. Genetics of resistance to bacterial leaf blight in rice germplasm in Uganda. In Second RUFORUM Biennial Meeting 20-24 September 2010.

Pangan, D. P. T. 2007. Informasi perkembangan serangan OPT padi tahun 2006, tahun 2005, dan rerata 5 tahun (2000-2004). Direktorat Jendral Tanaman Pangan, Jakarta. 192p.

Pautasso, M., Döring, T. F., Garbelotto, M., Pellis, L., \& Jeger, M. J. 2018. Impacts of climate change on plant diseases-opinions and trends. European Journal of Plant Pathology, 133(1), 295-313.

Pertanian, D. J., \& Hewan, K. 2017. Kementerian Pertanian Republik Indonesia. 2017. Statistik Data Kementrian Pertanian Selaras dengan data BPS.

Sudir, S. (2018). Epidemiologi, patotipe, dan strategi pengendalian penyakit hawar daun bakteri pada tanaman padi.

Siregar, A. Z. 2007. Hama-Hama Tanaman Padi. Universitas Sumatra Utara. Medan.

Untung, K. 2010. Diktat dasar-dasar ilmu hama tanaman. Jurusan Hama dan Penyakit Tumbuhan, Fakultas Pertanian UGM. Yogyakarta. 